\title{
Status of the fringing coral reefs in the southern Egyptian coast of the Red Sea
}

\author{
Tamer M. Attalla ${ }^{1}$, Mohammed M. A. Kotb ${ }^{2}$, Mahmoud H. Hanafy ${ }^{2}$ and \\ Saad Z. Mohammed ${ }^{2}$ \\ 1-Red Sea Protectorates, EEAA, Hurghada, Egypt, \\ 2-Marine Science Department, Faculty of Science, Suez Canal University, 41552 \\ Ismailia, Egypt \\ Corresponding author: tamer_m_attalla@yahoo.com
}

\section{ABSTRACT}

Study of the effect of human impact and sheltering condition on corals and fish assemblages was carried out in twenty nine reef sites at the area between Marsa Umm El-Grifate and Marsa Shuna, Red sea. Total living covers, total coral cover, and total recruitment colonies were recorded and exhibited higher percentages of occurrence on the exposed and un-impacted sites than on the sheltered and impacted ones. In contrary, the covers of algae, dead and bleached coral colonies were found to be higher on the sheltered and impacted reefs than on the exposed and un-impacted ones. In total, 117 fish species belong to 24 families were recorded. Although, carnivore fish were dominating the food web, the most abundant groups were found to be herbivore and planktivore fishes. Total fish abundance was higher in the shelter sites than in the exposed ones, while the abundance of herbivores, carnivores, and piscivores were higher in the sheltered and impacted sites than in the exposed and unimpacted ones. Total coral cover and total recruitments were negatively correlated to algal cover. Total fish abundance was positively correlated to total living cover and negatively correlated to total coral cover. Herbivores fish abundance was positively correlated to total coral cover and total recruitments, but it was negatively correlated to algal cover. Moreover, planktivores fishes were negatively correlated to the total coral cover and total recruitments. This study strongly recommended to organize the fishing activities along the southern Red Sea, in addition to regulate the rabid coastal development to this part of the Red Sea.

Keywords: Coral reef, Coral reef fishes, Relationship, Marsa Alam, Red Sea, Egypt.

\section{INTRODUCTION}

Coral reefs are the most structurally complex and taxonomically diverse marine ecosystems on earth, providing habitats for tens of thousands of associated fishes and invertebrates (Mellin et al., 2010; De'ath et al., 2012). Despite occupying less than $0.1 \%$ of the world's marine environment (Spalding et al., 2001), coral reefs host almost $30 \%$ of all the marine biodiversity (i.e. 93,000 described coral reefs organisms on a total of 274,000 described marine species (Porter and Tougas, 2001).

Threats to coral reefs and the ecosystem goods and services they provide are both natural and anthropogenic in origin. Coral reefs and associated ecosystems have a high degree of natural variability due to large-scale episodic disturbances such as major storms; hurricanes; typhoons; and cyclones (Wilkinson, 2004; Bruckner et al., 2011). Coral reefs are seriously threatened both locally and globally by a variety of direct and indirect anthropogenic threats (Jackson et al., 2001, Halpern et al., 2008; Jessen et al., 2012; De'ath et al., 2012; Granados- Cifuentes et al., 2013). Of primary concern are threats to ecosystem health from overexploitation of marine resources; 
destructive fishing practices; runoff of sediments and nutrients from poor land use practices; coastal development and uncontrolled tourism activities (Wilkinson, 2008; Halpern et al., 2008; Bruckner et al., 2011). Climate change also represents a new and increasing threat to coral reefs and associated ecosystems worldwide (Barshis et al., 2013; Mumby et al., 2014).

Coral reef fish's comprise the most species assemblages of vertebrates on the Earth and in the coral reef ecosystem, fish are the most visible and important mobile component (Froese and Pauly, 2011). Taxonomically, reef fishes are dominated by about 30 families, and some of the major families of coral reef fishes are classified by feeding strategy, with different major groups recognized; herbivores, carnivores, picsivores, coralivores, planktivores and omnivores (Morton et al., 2008; Cole, 2010; Alevizon, 2014).

The Red Sea has high biodiversity, including approximately 300 reef-building coral species and over 1400 fish species, also the biological diversity of other animals and plants associated with coral reefs is also high (Kotb et al., 2008; Hilimi et al., 2012; Mohammed, 2012). Coral reefs in Red Sea, like much of the rest of the world's reefs, are being degraded by a host of human and natural factors. Wind driven, waves, tropical storms, tides, temperature and salinity and outbreaks of COTs are consider as the natural impacts on the coral reefs in Red Sea (Kotb et al., , 2004, 2008; PERSGA, 2010), but the greatest threats generated by human activities are indicated to be pollution, sedimentation, unsustainable fishing activities, physical damage due to diving pressure, ship grounding and anchoring, sewage and wastewater disposal, increasing of costal developments, (Mohammed, 2006; 2012; Jameson et al., 2007; Kotb et al., , 2004, 2008; Attalla, 2011; ICRI, 2012).

Coral reef fish assemblages of the Red Sea are as varied as the reefs themselves (Roberts et al., 1992). In the Red Sea, like much of the world's reef fishes, are being rapidly degraded by human and natural factors including over fishing and using destructive methods of fishing, coastal developments and loss of habitats for nursery ground, oil pollution and others pollutants from human activities, climate change and reef degradation due to natural factors, e.g. natural predators (Feary et al., 2007; Bruckner et al., 2011).

While the diversity of reef fishes is influenced by the complexity of the reef habitat created by corals, fishes are also an important, dynamic component of this unique ecosystem. Through interactions at virtually all trophic levels, coral reef fishes modify the reef community structure and help to maintain the health of the associated habitat forming corals. They are major conduits for the movements of energy and nutrients into, within, and out of the reef ecosystem (Hobson, 1991; Bellwood and Wainwright, 2002).

The available published data revealed a shortage of data concerning the healthiness, coral status, and reef fishes at the study area. The present study tackled this issue and investigated the impact of human activities and threats on the reef communities at the concerned area. Furthermore, the study is describing the ecological relations between corals and reef fish communities, as well as the physical and human impacts on coral reef community health.

\section{MATERIALS AND METHODS}

\section{Study area:}

The study was carried out on the southern Egyptian Coast of the Red Sea, in the area between Marsa Umm El Grifate to Marsa Shuna (North of Marsa Alam Town), 
(Figure 1). The study area became well developed in the last ten years, where numerous touristic activities (i.e. resorts and hotels) were constructed along the shoreline of the area. A total of 29 reef sites were surveyed with distance intervals of approximately $500 \mathrm{~m}$ apart. Out of them, 4 are considered sheltered sites (i.e. Marsa), namely: Marsa Umm El Grifate, Marsa Ghaleb, Marsa Imbarek, and Marsa Shuna (sites 1,17,24,29, respectively). The four Marsa have different types of touristic activities, i.e. resorts, diving, snorkeling, picnic beaches, and diving boats mooring areas. The other 25 sites were considered exposed and some human impacts like some resorts.

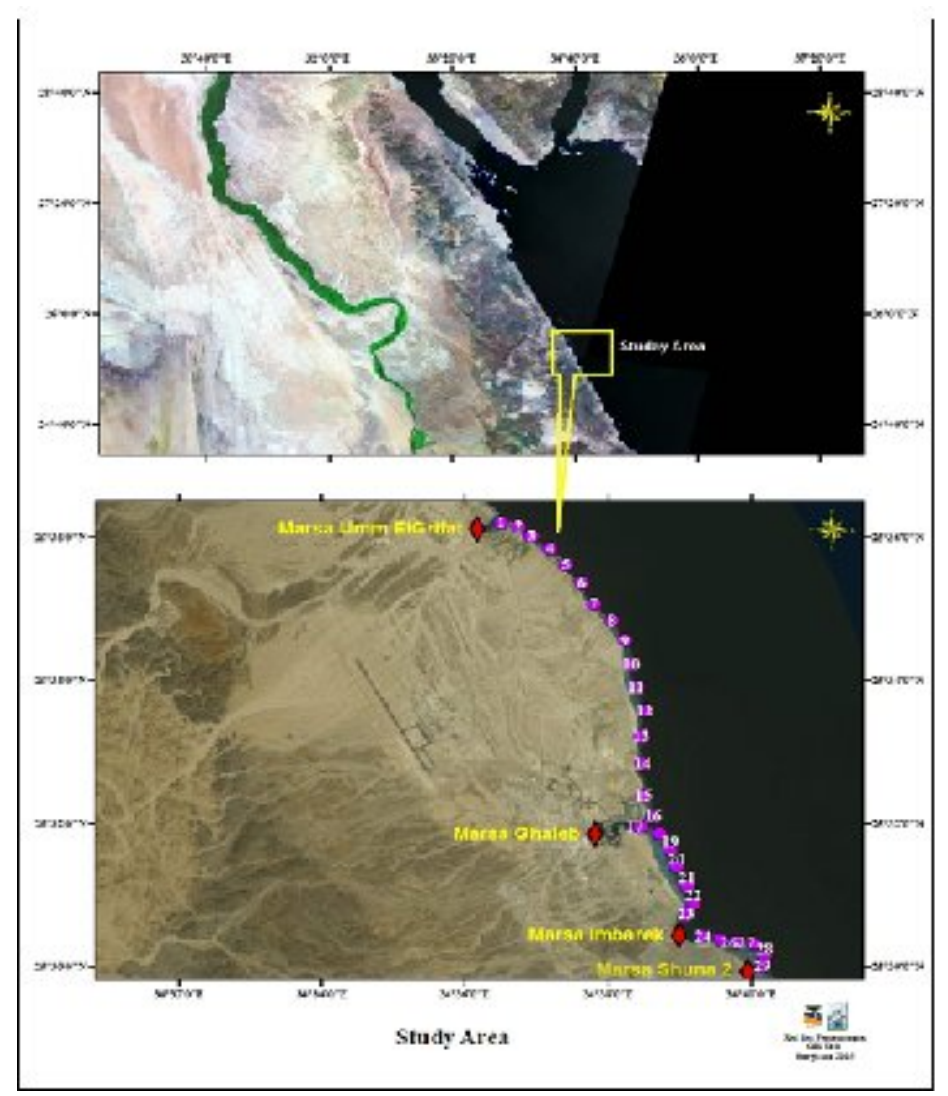

Fig. 1: Details of the study area at the southern Egyptian Red Sea

\section{Methodology:}

The study area was surveyed using SCUBA diving and commenced in November 2012. The substrate type was surveyed using Point Intercept Transect (PIT), the substrate indicators were surveyed using Belt Transect (BT), and the fish was surveyed using visual census method (English et al., 1997). At each site, 25m long transects parallel to the reef edge was surveyed at depth of $0-5 \mathrm{~m}$. The substrate type was recorded at $1 \mathrm{~m}$ intervals of the transect, i.e. 25 points were recorded at each transect. The recorded substrate types were hard coral (recorded at genus level), soft coral (recorded at genus level), algae, and dead substrate.

On the same transects, three belt transects each $25 \mathrm{~m}$ length and $5 \mathrm{~m}$ width (as replicates) were surveyed as BT. In each BT, substrate indicators of human impacts and reef health were recorded as: number of dead coral colonies (recently and old), bleached coral colonies (partially and totally), and new coral recruitments. These indicators were counted as number of category per $125 \mathrm{~m}^{2}$ area. 
On the other hand, the fish assemblages were also identified and counted at the same transacts locations. Fishes were identified at species level and grouped and classified into sex categories according to their feeding type, i.e. picsivores, carnivores, herbivores, coralivores, planktivores, and omnivores (Froese and Pauly, 2003; Cole, 2010; Alevizon, 2014). The fish census was made during daytime. At each site, coral reef fishes were counted within three transects (as replicates) of $100 \mathrm{~m}$ long, $5 \mathrm{~m}$ wide and $1 \mathrm{~m}$ height from the bottom. Fish counts were expressed as fish per $500 \mathrm{~m}^{3}$.

The data was analyzed statistically using IBM SPSS (V.19. Analysis of Variance (ANOVA) was applied to test the occurrence of significant differences between different variables of sheltering condition, human impact and different categories of fish assemblages and coral community. Furthermore, correlation was made to deduce the relationship between these different categories of fish assemblages and coral community.

\section{RESULTS}

\section{Substrate Composition at the study area:}

Regardless sites and human impacts, data of total living cover, hard coral, soft coral, algal turfs, non-living cover, dead coral, bleached colonies, and total recruitments colonies showed that the sheltering conditions had a significant influence on the total living cover, hard coral, algal turfs, and total recruitments colonies $(\mathrm{P}<$ $0.05)$ and did not show influence on the others studied categories $(\mathrm{P}>0.05)$. On the other hands, one way ANOVA showed non-significant values between the human impacts and all the studied substrates categories $(\mathrm{P}>0.05)$.

Table (1) shows the average covers of substrate categories after grouping the study sites as sheltered, exposed, or impacted and un-impacted sites. The four categories, total living cover, hard corals, bleached corals, and total recruitments showed higher values in both the exposed and un-impacted sites. In contrary, three categories, non-living cover, soft corals, and algal turfs, showed the opposite pattern with higher values in both the sheltered and impacted sites. Furthermore, the dead colonies intensity was higher in the exposed and impacted sites than in the sheltered and un-impacted sites.

Table 1: Means of different substrate categories at different sheltering condition and human impacts.

\begin{tabular}{|c|c|c|c|c|}
\hline \multirow[b]{2}{*}{ Substrate Categories } & \multicolumn{2}{|c|}{ Sheltering condition } & \multicolumn{2}{|c|}{ Human impacts } \\
\hline & $\begin{array}{c}\text { Sheltered } \\
\text { Sites }\end{array}$ & $\begin{array}{c}\text { Exposed } \\
\text { Sites }\end{array}$ & $\begin{array}{l}\text { Un-Impacted } \\
\text { Sites }\end{array}$ & $\begin{array}{c}\text { Impacted } \\
\text { Sites }\end{array}$ \\
\hline Total living cover $(\%)$ & 82.8 & 87.4 & 87.6 & 85.1 \\
\hline Non-living cover $(\%)$ & 17.2 & 12.6 & 12.5 & 14.9 \\
\hline Hard coral $(\%)$ & 56.7 & 78.8 & 77.7 & 71.3 \\
\hline Soft coral $(\%)$ & 6.5 & 2.7 & 3.1 & 3.4 \\
\hline Algal Turfs (\%) & 19.7 & 6.0 & 6.8 & 10.4 \\
\hline Dead colonies (colony $/ 125 \mathrm{~m}^{2}$ ) & 26.7 & 29.2 & 28.4 & 30.0 \\
\hline Bleached colonies (colony/125m²) & 0.6 & 1.9 & 2.2 & 0.7 \\
\hline Total recruitment colonies (colony $/ 125 \mathrm{~m}^{2}$ ) & 15.7 & 52.4 & 50.6 & 40.1 \\
\hline
\end{tabular}

In general, the total living cover at the studied sites ranged between $80 \%$ at sites 23, 24 and $92 \%$ at sites 7,8,9,10 and 18 (Fig. 2). The highest value of hard coral coverage $(92 \%)$ was recorded at sites 12,18 and the lowest one $(48 \%)$ was recorded at site 23 , but the highest soft coral coverage (12\%) recorded at site 6 and the lowest 
one (1\%) at site 22 , (Fig. 3). Site 23 had the highest value of algal turfs $23 \%$ and site 11 had the lowest one (1\%) (Fig. 4). The dead colonies were ranged between 8 and 50 colonies $/ 125 \mathrm{~m}^{2}$ at sites 29 and 8 , respectively, while the bleached colonies ranged between 1 and 12 colonies $/ 125 \mathrm{~m}^{2}$ at sites $(17,22,27,28)$ and site 6 respectively, (Fig. 5).

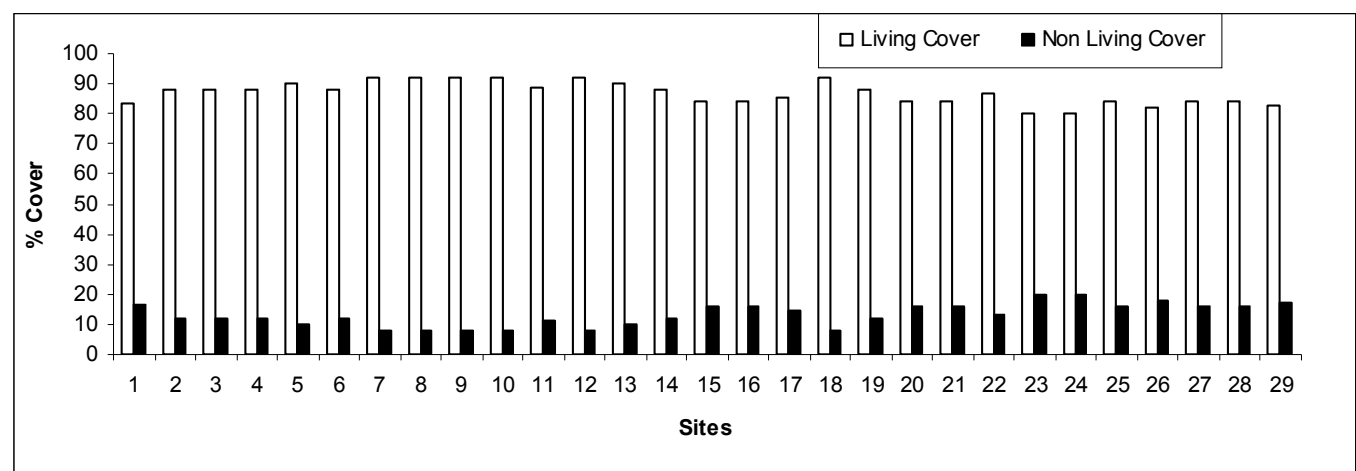

Fig. 2: The recorded living and non-living cover in the study sites

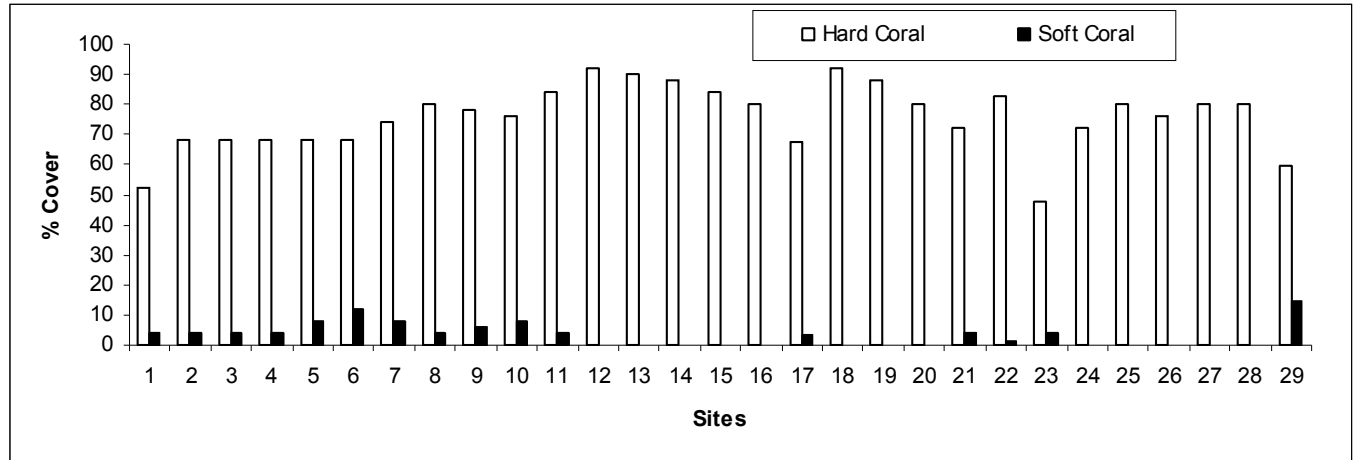

Fig. 3: The recorded hard and soft coral cover in the study sites

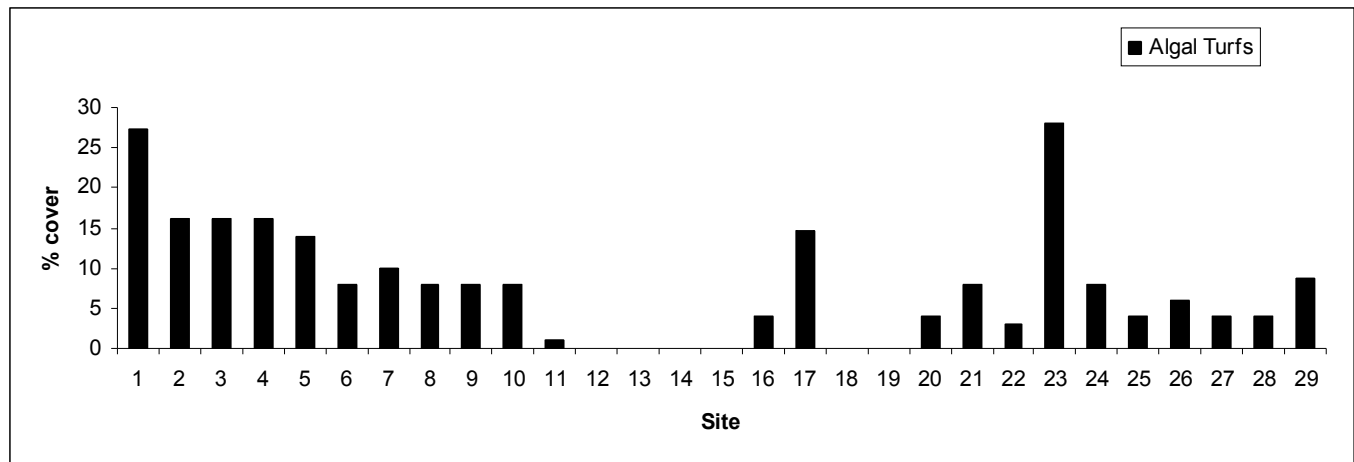

Fig. 4: The recorded algal turf covers in the study sites

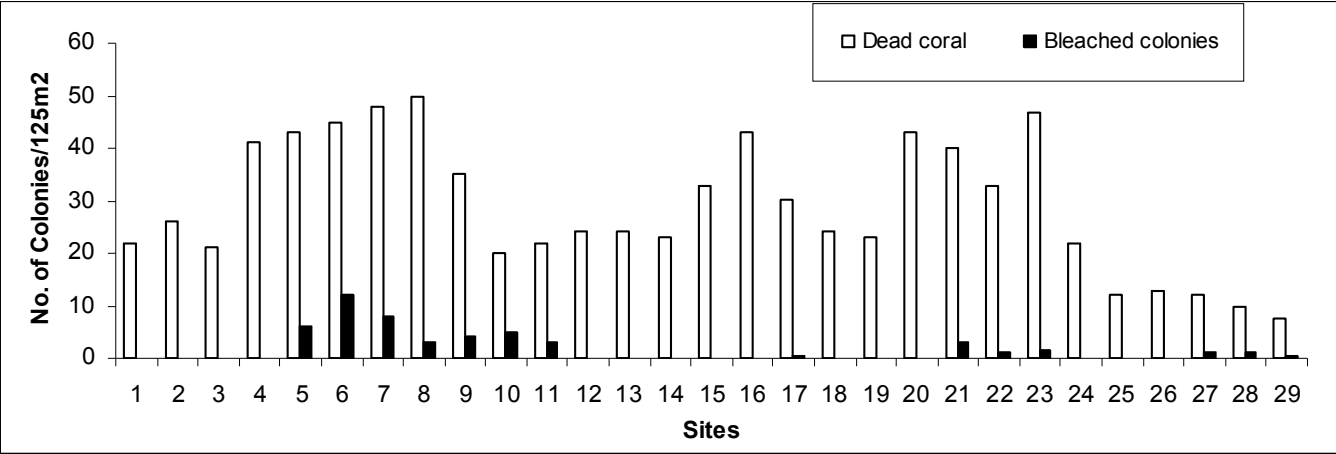

Fig. 5: The recorded number of dead and bleached colonies in the study sites 
On the other hand, the highest number of recruitment colonies $\left(95\right.$ colonies $\left./ 125 \mathrm{~m}^{2}\right)$ recorded at sites $16 \& 20$ and the lowest one $\left(8\right.$ colonies $\left./ 125 \mathrm{~m}^{2}\right)$ was recorded at site 1 (Fig. 6).

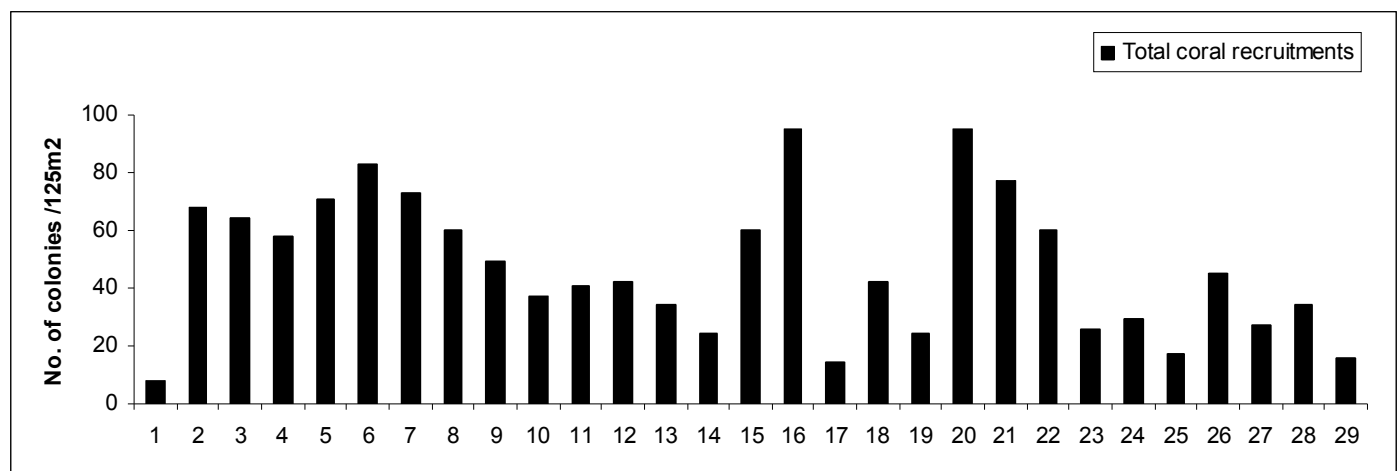

Fig. 6 The recorded total number of coral recruitments in the study sites

\section{Fish assemblage at the study area:}

During this study, 117 fish species belong to 24 families were recorded in the study area. Among these species, 9 species were picsivores, 61 species were carnivores, 19 species were herbivores, 7 species were coralivores, 8 species were planktivores, and 13 species were omnivores. Testing the effect of sheltering condition on the fish assemblage using one way ANOVA showed that sheltering condition affected significantly the total fish abundance, as well as the abundances of each of the herbivores, carnivores, planktivores, and omnivores fishes $(p<0.05)$. No significant effect was detected on the abundances of piscivores and coralivores fishes $(\mathrm{p}>0.05)$. On the other hand, the human impacts had significant influence on the herbivores, carnivores, and omnivores fishes, but it did not significantly influence the other fish assemblages $(\mathrm{p}>0.05)$.

Regarding the sheltering and human impacts, the abundance of fish assemblage at the study area is shown in Table (2). The herbivores showed the highest abundance in all conditions, while the coralivores and piscivores shared the lowest abundances. According to the sheltering condition, the total fish abundance showed higher value at the sheltered sites than at the exposed sites while there was no difference in the total fish abundance between the impacted and un-impacted sites. Herbivores, carnivores, planktivores, and piscivores abundances were higher in sheltered and impacted sites than at the exposed and un-impacted sites. On the other hand, omnivores and coralivores abundances were higher at the exposed and un-impacted sites, than at sheltered and impacted ones.

Comparing sites, the highest fish abundance was recorded in site 25 and the lowest one in site 21 and being 1738 and 325 fish $/ 500 \mathrm{~m}^{3}$, respectively (Fig. 7). Fig. (8) shows the abundance of each feeding groups at the studied sites. Site 25 had the highest abundance of carnivores and omnivores fishes (191 and $995 \mathrm{fish} / 500 \mathrm{~m}^{3}$, respectively) and site 29 had the lowest ones (14 and 16 fish $/ 500 \mathrm{~m}^{3}$, respectively). The highest abundance of planktivores fishes was recorded in site 26 and the lowest one recorded in site 2, ( 852 and 2 fish $/ 500 \mathrm{~m}^{3}$, respectively). The abundance of coralivores fishes ranged between 4 and 53 fish $/ 500 \mathrm{~m}^{3}$ (recorded in sites 16 and 27, respectively), and the abundance of piscivores ranged between 2 and $63 \mathrm{fish} / 500 \mathrm{~m}^{3}$, (in sites 18 and 11, respectively). Site 29 had the highest abundance of herbivores fishes while site 28 had the lowest one ( 430 and $65 \mathrm{fish} / 500 \mathrm{~m}^{3}$, respectively). 
Table 2: The recorded average of fish assemblage in the study sites regarding the different sheltering conditions and human impacts.

\begin{tabular}{|l|c|c|c|c|}
\hline \multirow{2}{*}{$\begin{array}{c}\text { Fish community } \\
\left(\text { fish/500m }{ }^{3}\right)\end{array}$} & \multicolumn{2}{c|}{ Sheltering condition } & \multicolumn{2}{c|}{ Human impacts } \\
\cline { 2 - 5 } & $\begin{array}{c}\text { Sheltered } \\
\text { Sites }\end{array}$ & $\begin{array}{c}\text { Exposed } \\
\text { Sites }\end{array}$ & $\begin{array}{c}\text { Un-Impacted } \\
\text { Sites }\end{array}$ & $\begin{array}{c}\text { Impacted } \\
\text { Sites }\end{array}$ \\
\hline Total fish abundance & 1007.5 & 648.1 & 697.0 & 699.3 \\
\hline Herbivores Fishes & 408.5 & 248.0 & 259.4 & 274.9 \\
\hline Carnivores Fishes & 67.3 & 38.3 & 44.9 & 71.5 \\
\hline Piscivores Fishes & 29.5 & 21.1 & 18.1 & 24.1 \\
\hline Coralivores Fishes & 16.9 & 27.3 & 23.7 & 15.9 \\
\hline Omnivores Fishes & 102.3 & 143.6 & 140.7 & 131.7 \\
\hline Planktivores Fishes & 401.8 & 151.3 & 169.8 & 221.5 \\
\hline
\end{tabular}

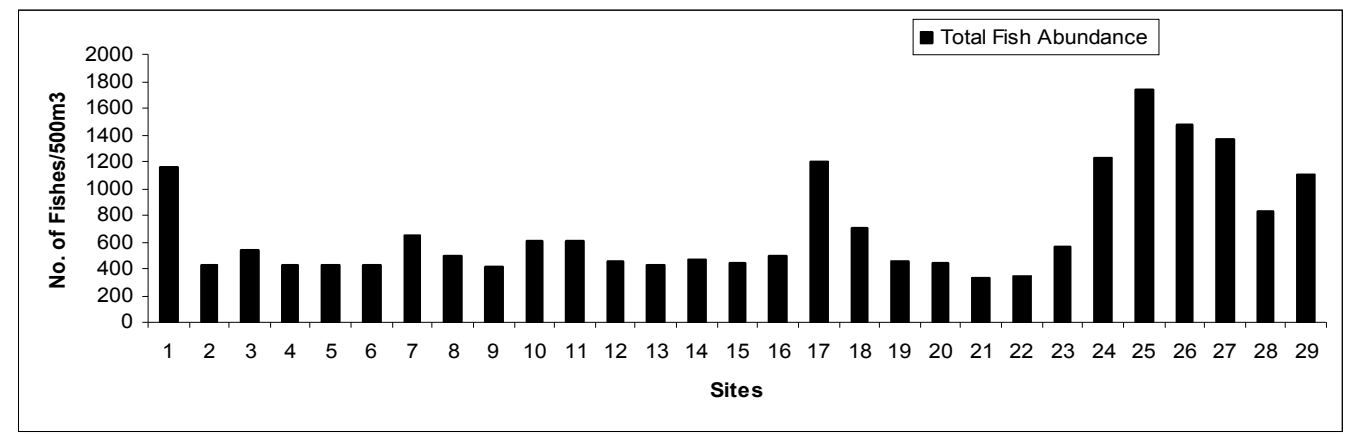

Fig.7: The recorded total fish abundance in the studied sites

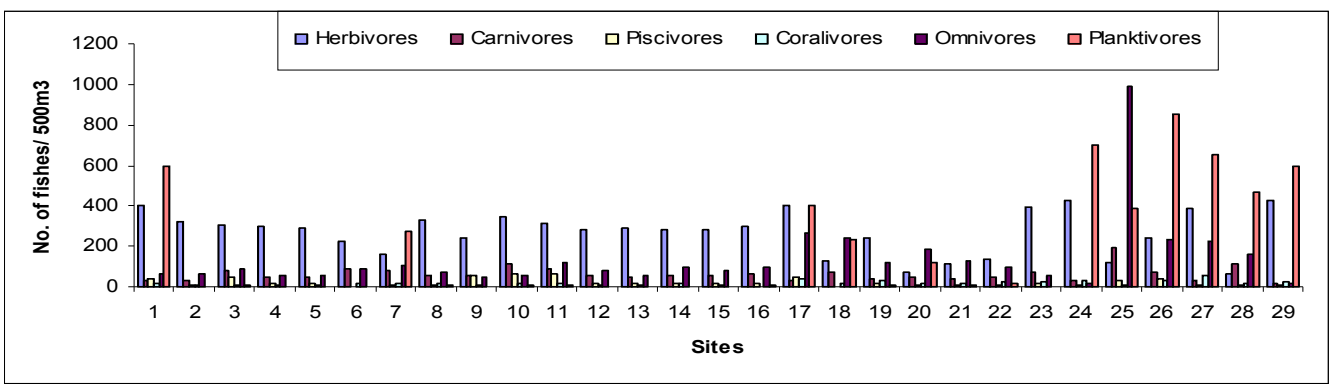

Fig. 8: The abundance of the different fish grouped according to their feeding type in the study sites

\section{Relation between substrate composition and fish assemblages:}

The inter-relationships between the different substrate categories and the different fish assemblages were investigated using correlation test and results are given in Table (3). No correlation was detected between the total coral coverage and the total recruitment colonies $(\mathrm{p}=0.367)$. On the other hand, the algal turfs showed significant negative correlation with the coral coverage $(p=0.001)$ and no correlation with the total recruitment colonies $(p=0.585)$. The total fish abundance showed significant positive correlation with the total living cover $(\mathrm{p}=0.001)$, and no correlation with the algal turfs $(\mathrm{p}=0.25)$. On the other hand, the total fish abundance had significantly negative correlation with the total coral cover $(p=0.028)$ and total recruitment colonies $(p=0.003)$. Herbivores fish abundance had no correlations with the total coral cover $(p=0.21)$, total recruitment colonies $(p=0.925)$, and algal turfs $(p=0.265)$. Moreover, the coralivores fishes showed no correlation with the total coral cover $(p=0.875)$. On the other hand, the abundance of planktivores fishes had significantly negative correlation with the total coral cover $(p=0.047)$ and total recruitment colonies $(\mathrm{p}=0.002)$. 
Table 3:The inter-relationships between substrate composition and fish assemblages. The liner equation and significant values are shown as well

\begin{tabular}{|c|c|c|c|c|}
\hline $\mathbf{Y}$ & $\mathbf{X}$ & equation & b & P-Value \\
\hline Total Coral Cover & Total Coral Recruitments & $\mathrm{Y}=75.79+0.066 \mathrm{X}$ & 0.066 & 0.367 \\
\hline Total Coral Cover & Algal Turfs & $\mathrm{Y}=87.86-1.134 \mathrm{X}$ & -1.134 & 0.001 \\
\hline Total Coral Recruitments & Algal Turfs & $\mathrm{Y}=50-0.342 \mathrm{X}$ & -0.342 & 0.585 \\
\hline Total Fish abundance & Total Living Cover & $\mathrm{Y}=6111.04+62.17 \mathrm{X}$ & 62.17 & 0.001 \\
\hline Total Fish Abundance & Total Coral Cover & $\mathrm{Y}=2153.47-18.234 \mathrm{X}$ & -18.234 & 0.028 \\
\hline Total Fish Abundance & Algal Turfs & $\mathrm{Y}=618.69+12.14 \mathrm{X}$ & 12.14 & 0.25 \\
\hline Total Fish Abundance & Total Coral Recruitments & $\mathrm{Y}=1209.7-10.47 \mathrm{X}$ & -10.47 & 0.003 \\
\hline Herbivores Fish Abundance & Total Coral Cover & $\mathrm{Y}=48.308+2.680 \mathrm{X}$ & 2.68 & 0.21 \\
\hline Herbivores Fish Abundance & Total Coral Recruitments & $\mathrm{Y}=263.5+0 . .78 \mathrm{X}$ & 0.78 & 0.925 \\
\hline Herbivores Fish Abundance & Algal Turfs & $\mathrm{Y}=283.1-2.95 \mathrm{X}$ & -2.95 & 0.265 \\
\hline Coralivores Fish Abundance & Total Coral Cover & $\mathrm{Y}=15.2+0.039 \mathrm{X}$ & 0.038 & 0.875 \\
\hline Planktivores Fish Abundance & Total Coral Cover & $\mathrm{Y}=1002.98-10.355 \mathrm{X}$ & -10.255 & 0.047 \\
\hline Planktivores Fish Abundance & Total Recruitment Colonies & $\mathrm{Y}=473.67-6.087 \mathrm{X}$ & -6.087 & 0.002 \\
\hline
\end{tabular}

\section{DISCUSSION}

The main reef type in the Red Sea is the finishing reefs which are characteristic with wide back reef in some region and a lot of bays and lagoons, and is sheltered from the northern wave in most time of the years (Edwards and Head, 1987). In the last two decades the coral reef degradation particularly along Egyptian Red sea coast was due to enhanced anthropogenic disturbances and their interaction with natural stressors ((Kotb et al., 2004, 2008; Ali et al., 2011).

During the present study, sheltering condition showed an influence on the total living cover at the study area. This observation agrees with that of Attalla (2011), who studied the effect of the sheltering condition on the substrate composition at the northern Red Sea and found similar pattern. In addition, the results from the reef assessments in the Red Sea over two decades 1988-1997 on the Egyptian reefs suggest a little change in community structures with the temporal change (Riegl et al., 2012). The total living cover in all sites did not affected with the occurred human impact such as coastal development, diving activities and some fishing activities. Moreover, the sheltered and impacted sites (Marsa) had lower living cover than exposed and un-impacted sites. These findings agrees with Mohammed (2012) and Dar et al., (2012) as they found in the southern Red Sea that the un-impacted sites had higher total living cover than the impacted sites.

The variation in the coral communities between exposed and sheltered reefs are well documented in different parts of the world (Toda, 2007). In additional, Tilot et al., (2008); Attalla (2011); Mohammed (2012) and Dar et al., (2012) found that in the exposed sites, branched forms estimated higher percentage than in the sheltered sites, in contrast, the massive growth forms at the sheltered sites showed higher occurrence than at the exposed site. This explains the highest cover of coral cover in exposed sites than sheltered one. Generally, the total coral coverage in the un-impacted sites showed insignificant increase than in the impacted ones (e.g. Kaufman and Tschirky, 2010; Obura and Mangubhai, 2011; Kaufman et al., 2011; ICRI, 2012; Jackson et al., 2014). The losses of marine habitats are the highest in coastal areas largely as a result of conflicting uses of coastal habitats due to the coastal development which increased in last two decade Southern Red Sea and these by turn effects on the diversity of species in the some reefs and the variation between them in the tolerance and stress (Riegl et al., 2012). 
During this study the exposed and un-impacted sites had lower algal cover than the sheltered and impacted sites. Jenkins et al., (1999), studied the algal composition in inshore sites at the south of the Isle of Man, UK, and he found that the sheltered sites had wide algal diversity and coverage in the sheltered sites than in the exposed sites.

The detected number of dead coral colonies in the sheltered and impacted sites was higher than those in the exposed and un-impacted sites. The dramatic variations in temperature and salinity can cause high mortality rates of corals (Brown, 2000; Mohammed and Mohamed, 2005) especially in sheltered and semi-closed areas.

The total number of recruitment colonies was higher in the exposed and unimpacted sites than in the sheltered and impacted ones. Increasing the number of recruitment colonies in the exposed sites and un-impacted sites could be a result of successful settlements of coral larvae and availability of settlement space in these sites compared to the sheltered and impacted sites. In the sheltered and impacted sites, the continuous supply of fine and particulate sediments may impede the larval settlements and/or prevent their growing up through reduced illumination and the lack of suitable surfaces for larval settlements and colony growth (Sheppard, 1982; Tilot et al., 2008; Gleason and Hofmann, 2011). Also, the algal flora may displace and growing faster and obscures the new coral recruits, (Dar et al., 2012).

During the present study, 117 fish species belong to 24 families were recorded dominated by carnivores. The total fish abundance was higher in the sheltered sites than in the exposed sites. This might be due to the coastal development and diving activities in the sheltered sites, which prevent any fishing activities in these areas.

Regarding the feeding habits, herbivores and planktivores fishes densities were the highest in the studied sites. The lowest groups were picsivores and corallivores fishes in all sites. Pomacentridae, and Acanthuridae which were the most dominant families of the planktivores and herbivores, respectively, were the most dominated of fish fauna in terms of species richness along the Egyptian Red Sea reefs (Alwany and Stachowitsch, 2007). Alwany $(2011 ; 2014)$ confirmed that these groups were the most abundant ones in some of studied sites within the study area and the lowest abundant groups were picsivores and corallivores fishes .On the other hands, the abundance of herbivores and carnivores and picsivores fishes was high at the sheltered and impacted sites than exposed and un-impacted ones. This might be attributed to that the major species of these groups were commercial fishes, used by human as food source. Most of sheltered sites were marsa and house reefs did not performed any fishing activates expect but most exposed sites were used for fishing activates from the coast by local peoples. Shepperd et al. (1992) stated some coral reef fishes are used in trade and become the food source like Labridae, Serranidae, Lethrinidae, Lutjanidae and Siganidae. In the last two decades, increased human settlement in coastal areas of the Red Sea and the resultant increase in artisanal and commercial fishing activities to support local consumption, and to supply a growing international trade in coral reef species and products, have led to depletion of many commercially valuable species (Bruckner et al., 2011).

As the coral reef ecosystem contains different elements such as corals, associated fauna and flora fishes and others, interact with each other in different relationships. Many studies showed that, the factors that control the presence of adult corals at any reef are the same which control the occurrence of coral recruitments, such as light (Banaszak and Lesser, 2009), hydrostatic pressures (Stake and Sammarco, 2003) sedimentation (Heyward and Negri, 2010) and currents (Gleason et al., 2009). This by the way makes the reefs that are healthy and have high coral 
coverage more attractive to the coral larvae (Sale et al., 2005). This was the same observation during this study; where we found positive correlation between the coral coverage and the total number of recruitments. In addition, both substrates elements; coral coverage and coral recruitments found to be in a negative significant correlation with algal turfs. Hughes et al. (2007) stated that a change in the coral-dominated reefs to alternative stable states are controlled by algae. Also, the availability of the settlement space can be reduced and intensity of interactions between corals and algae can be increased (Done, 1992; Hoey and Bellwood, 2011), and reduce in habitat complexity (Mumby and steneek, 2011).

Coral reef fishes, especially those depend on living substrates are known to be influenced significantly by changes in living substrates elements (Pratcchett et al., 2011, 2012). The correlation between the living substrate and total fish abundance in the present study found to be positively correlated. Alwany and stachowisch (2007) found significant effect of the living substrates on the distribution and abundance of common reef fishes in the Red Sea. The negative correlation between the total fish abundance and coral cover and coral recruitments in the present study is mainly due to about $50 \%$ of the total fish abundance belongs to planktivores fishes and these groups of fishes are strongly negative correlated to both the coral cover and coral recruitments.

Predation is generally assumed to be the major source of larval mortality for corals and other benthic invertebrates (Young and Chia, 1987). Coral eggs and larvae are highly nutritious, containing 50-70 \% lipid (Richmond, 1987; Arai et al., 1993). Furthermore, they are large and colorful with no obvious morphological or known physical defense against predators (Harrison and Wallace, 1990). Pratchett et al. (2000), studied the comparative palatability among eggs of mass-spawning corals at the Orpheus Island in central section of the Great Barrier Reef, and they found that, the eggs and larvae of mass-spawning reef corals are seasonally abundant and highly nutritious and are therefore a potentially important food source for planktivores fishes. Others studies found the negative relationship between the coral coverage like Munday et al. (1997); Gardiner and Jones (2005) and Pratchett et al. 2012).

During this study, abundance of herbivores fishes found to be had a nonsignificant relationship with the total coral coverage and total recruitment colonies, and algal turfs. Several studies have demonstrated a critical role of herbivores reef fishes in influencing competitive interactions between corals and algae (Mumby et al., 2006, 2007; Hughes et al., 2007, 2011), and consequently coral reef resilience (Nyström and Folke, 2001; Bellwood et al., 2004). Many of these studies have demonstrated a strong negative relationship between fish grazing intensity (particularly biomass) and algal cover with increasing in coral cover (Arnold, 2010; Smith, 2010; Mumby and Steneek, 2011).

Corallivors fishes abundance found to have non significance correlation with the coral coverage. These groups of fishes are well studied in many region of the world and two theories were hypotheses. First which found a strong correlation with coral coverage , (e.g; Alwany, 1997, 2003,2013,2014; Ohman et al., 1998), and the second, found no correlation between the corallivores and coral coverage and that due to the food availability are more than their needs, (e.g. Attalla, 2011; Lawton and Pratchett, 2012; Pratche et al., 2012). The present study agrees with the second hypothesis.

Finally, this study is the first to give detailed view on the status of coral reef and coral reef fishes along this part of the Egyptian coast of the Red Sea which are characterized by rapid coastal development and different anthropogenic impacts. It is important critical therefore, to established continuous monitoring programs, and 
gathered base-line data to help in the conservation and management of the reefs within this area.

\section{ACKNOWLEDGEMENT}

This work was funded and sponsored by Hurghada Environmental Protection and Conservation Association (HEPCA) as a part of a coastal survey project. The authors also thank Dr. Mohammed Abou El Regal, Ass. Prof of fishes, Marine Science Department, Faculty of Science, Port Said University, Dr Mohammed Ismail, Lecture of Microbiology- Marine Science Department, Faculty of Science, Suez Canal University. Dr. Mahmoud Maaty, National Institute of Oceanography and Fishers (Hurghada Branch), Mr. Amged El Shafay, Mr. Mohammed Negm, Mr., Islam El Sadek, Red Sea Protectorates, for their kindly helping to collect the field data of this study.

\section{REFERENCES}

Ali, A.A.M.; Hamed, M.A. and Abd El-Azim, H. (2011). Heavy metals distribution in the coral reef ecosystems of the Northern Red Sea. Helgoland Marine Research, 65: $67-80$.

Alevizon, W.S and Porter, J.W. (2015) Coral loss and fish guild stability on Caribbean coral reef: 1974-2000. Environmental Biology of Fishes.

Alwany, M.A. (1997). Ecological and biological studies on some coral reef fishes in south Sinai (Red Sea - Gulf of Aqaba). M. Sc. Thesis, Suez Canal University, Ismailia, Egypt; 283 pp.

Alwany, M.A. (2003). Ecological aspects of some coral reef fishes in the Egyptian coast of the Red Sea. Ph.D Thesis, University of Innsbruck - Innsbruck, Austria, 101pp.

Alwany, M.A. (2011). Community structure and fish assemblage at Marsa Abu Dabab, Red Sea. Egypt J. Aquat. Biol. \& Fish. 15 (2): 105- 124.

Alwany, M.A. (2014). Habitat diversity and fish communities on Marsa Gabal ElRosas reefs, Red Sea. CATRINA (2014), 9 (1): 15 -23.

Alwany, M.A. and Stachowitsch, M. (2007). Distribution and diversity of six common reef fish families along the Egyptian coast of the Red Sea. Journal of Fisheries and Aquatic Science 2 (1): 1-16.

Arai, T.; Kato, M.; Heyward, A.; Ikeda, Y.; Iizuka, T. and Maruyama, T. (1993). Lipid composition of positively buoyant eggs of reef building corals. Coral Reefs, 12:71-75.

Arnold, S.N.; Steneck, R.S. and Mumby, P.J. (2010). Running the gauntlet: inhibitory effects of algal turfs on the process of coral recruitment. Mar. Ecol. Prog. Ser. 414:91-105.

Attalla, T.M. (2011). Natural and Human Impacts on the coral Reef Of the Red SeaEgypt. M. Sc. Thesis, Suez Canal University, Ismailia, Egypt; 268 pp.

Banaszak, A. T., and Lesser, M. P. (2009). Effects of solar ultraviolet radiation on coral reef organisms. Photochemical and Photobiological Sciences, 8:12761294.

Barshis, D.J.; Ladner, J.T.; Oliver, T.A.; Seneca, F.O.; Traylor-Knowles, N. and Palumbi, S.R. (2013). Genomic basis for coral resilience to climate change. Proceedings of the National Academy of Sciences of the United States of America, 110: 1387-1392. 
Bellwood, D.R. and Wainwright, P.C. (2002) Chapter 1 The history and biogeography of fishes on coral reefs. In: Sale, P.F. Coral reef fishes. Academic Press, London.

Bellwood, D.R.; Hughes, T.P.; Folke, C. and Nyström, M. (2004). Confronting the coral reef crisis. Nature 429: 827- 833.

Brown, B.E. (2000). The significance of pollution in eliciting the cnidarians. International Journal for Environmental Pollution 13: 392-415.

Bruckner, A.W., Alnazry, H.H. and Faisal, M. (2011). A parading shift for fisheries management to enhance recovery, resilience, and sustainability of coral reef ecosystems in the Red Sea. Sustainable Fisheries: Multi-Level Approaches to a Global Problem, pp 85-111.

Bruno, J.F. and Bertness, M.D. (2001). Habitat modification and facilitation in benthic marine communities. In: Marine Community Ecology (ed. Bertness, M.D.). Sinauer Associates Inc., Sunderland, MA, pp. 201-218.

Caley, M. J. (1995). Reef-fish community structure and dynamics: an interaction between local and larger scale? Mar. Ecol. Prog. Ser, 129: 19-29.

Caley, M. J.; Carr, M.; Hiscor, H. M. A.; Huges, T. P.; Jones, G. P. and Menge, B. A. (1996). Recruitment and the local dynamics of open marine populations. Ann. Rev. Ecol. Syst., 27: 477-500.

Chabanet, P, Ralamboondrainy, H., Amanieu, M., Faure, G., Galzin, R. (1997). Relationships between coral reef substrata and fish. Coral Reefs, 16:93-102.

Christensen, J. D.; Jeffrey, C. F. G.; Caldow, C.; Monaco, M. E.; Kendall, M. S.and Appeldoorn, R.S. (2003). Cross-shelf habitat utilization patterns of reef fishes in southwestern Puerto Rico. Gulf Caribb. Res., 14: 9-28.

Cole, A.J. (2010). Cleaning to corallivory: ontogenetic shifts in feeding ecology of tubelip wrasse. Coral Reefs, 29:125-129.

Dar, M A.; Mohamad, T.A.; Mahmoud, I. E. (2012). Geomorphic and geographic distributions of reef-building and soft coral communities in the inshore zone of the Red Sea. Egyptian Journal of Aquatic Research, 38: 105-117.

De'ath, G.; Fabricius, K.E.; Sweatman, H.; and Puotinen, M. (2012). The 27-year decline of coral cover on the Great Barrier Reef and its causes. Proceedings of the National Academy of Sciences of the United States of America, 109: 17995-17999.

Doherty, P. J. (1991). Spatial and temporal patterns in recruitment. In: Sale, P.F. (ed), The ecology of fishes on coral reefs. Academic Press, San Diego, pp: 261-293.

Done, T. (1992). Phase shifts in coral reef communities and their ecological significance. Hydro biologia, 247:121-132.

Edwards, A.J. and Head, S. (1987). Key environments: Red Sea. Pergamon Press, Oxford, pp 45-68.

English, S.; Wilkinson, C. and Baker, V. (1997). Survey manual for tropical marine resources. Australian Institute of Marine Science, Townsville. Australia. pp3449.

Faunce, C. H. and Serafy, J. E. (2006). Mangroves as fish habitat: 50 years of field studies. Mar. Ecol. Prog. Ser, 318: 1-18.

Feary, D. A.; Almany, G. RJones, G. P., and Mccormick., M. I. (2007). Coral degradation and the structure of tropical reef fish communities. Mar. Ecol. Prog. Ser, 333: 243-248.

Fields, S. and Hubach, E. (2014). The relationship between wave action and algae communities. http://pbsci.ucsc.edu/ 
Froese R, and Pauly D (eds) (2003). FishBase. World Wide Web electronic publication, www.fishbase.org.

Froese, R. and Pauly, D. (2011). FishBase. World Wide Web electronic publication. www.fishbase.org, version (02/2011).

Friedlander, AM., and DeMartini, EE. (2002). Contrasts in density, size, and biomass of reef fishes between the northwestern and the main Hawaiian islands: the eVects of fishing down apex predators. Mar Ecol Prog Ser, 230:253-264.

Gleason, D.F., and Hofmann, D. (2011). Coral Larvae: from gametes to recruits. Journal of Experimental Marine Biology and Ecology, Volume 408, Issues 1-2, 15 November 2011, Pages 42-57.

Gleason, D.F.; Danilowicz, B.R. and Nolan, C.J. (2009). Reef waters stimulate substratum exploration in planulae from brooding Caribbean corals. Coral Reefs, 28: 549-554.

Granados-Cifuentes, C.; Bellantuono, A.J.; Ridgway, T.; Hoegh-Guldberg, O. and Rodriguez- Lanetty, M. (2013). High natural gene expression variation in the reef-building coral Acropora millepora: potential for acclimative and adaptive plasticity.BMC Genomics, 14: 228-240.

Halpern, B.S.; Walbridge, S.; Selkoe, K.A.; Kappel, C.V.; Micheli, F.; D’Agrosa, C.; Bruno, J.F.; Casey, K.S.; Ebert, C.; Fox, H.E.; Fujita, R.; Heinemann, D.; Lenihan, H.S.; Madin, E.M.P.; Perry, M.T.; Selig, E.R.; Spalding, M.; Steneck, R. and Watson, R. (2008). A global map of human impact on marine ecosystems. Science, 319: 948-952.

Harrison, P.L. and Wallace, C. C. (1990). Reproduction, dispersal and recruitment of scleractinian corals. In: Dubinsky Z (ed) Ecosystems of the world. 25. Coral reefs. Elsevier, Amsterdam, pp 133-207.

Heyward, A.J. and Negri, A.P. (2010). Plasticity of larval pre-competence in response to temperature: observations on multiple spawning coral species. Coral Reefs 29: 631-636.

Hilmi, N.; Safa A.; Reynaud, S. and Allemand, D. (2012). Coral Reefs and Tourism in Egypt Red Sea. Topics in Middle Eastern and African Econmies Vol. 14, 416:434.

Holbrook, S. J., Forrester, G. E. and Schmitt, R.J. (2000). Spatial patterns in abundance of a damselfish reflect availability of suitable habitat. Oecologia, 122: $109-120$.

Hobson, E. S. (1991). Trophic relationships of fishes specialized to feed on zooplankters above coral reefs. Pages $69-95$ in P.F. Sale, editor. The ecology of fishes on coral reefs. Academic Press, San Diego, California.

Hoey, A.S. and Bellwood, D.R. (2011). Suppression of herbivory by macroalgal density: a critical feedback on coral reefs? Ecol Lett, 14: 267-273.

Hughes, T.P.; Rodrigues, M.J.; Bellwood, D.R.; Ceccarelli, D.; Hoegh- Guldberg, O.; McCook, L.; Moltschaniwskyj, N.; Pratchett, M.S.; Steneck, R.S. and Willis, B. (2007). Phase Shifts, Herbivory and the Resilience of Coral Reefs to Climate Change. Curr Biol, 17: 1-6.

Hughes, T.P.; Graham, N.A.J; Jackson, J.B.C.; Mumby, P.J.; and Steneck, R.S. (2010). Rising to the challenge of sustaining coral reef resilience. Trend. Ecol. Evol, 25:633-640.

ICRI, (2012). International Coral Reef Initiative, Annual report, Status of Coral Reef around the World.

Jackson, J.B.C.; Kirby, M.X.; Berger, W.H.; Bjorndal, K.A.; Botsford, L.W.; Bourque, B.J.; Bradbury, R.H.; Cooke, R.; Erlandson, J.; Estes, J.A.; Hughes, 
T.P.; Kidwell, S.; Lange, C.B.; Lenihan, H.S.; Pandolfi, J.M., Peterson, C.H.; Steneck, R.S.; Tegner, M.J.; and Warner, R.R., (2001). Historical over-fishing and the recent collapse of coastal ecosystems. Science, 293: 629-638.

Jackson, J.B.C.; Donova, M.K.; Cramer, K.L. and Lam, V.V. (2014). Status and Trends of Caribbean Coral Reefs: 1970-2012. Global Coral Reef Monitoring Network, IUCN, Gland, Switzerland.

Jameson, S.C.; Ammar, M.S.A.; Saadalla E.; Mostafa, H.M. and Riegl, B. (2007). A quantitative assessment of diving sites in the Egyptian Red Sea during a period of severe anchor damage: A baseline for restoration and management. Journal of Sustainable Tourism, Vol. 15 (No.3).

Jenkins, S.R.; Trevor A. Norton, T.A. and Hawkins, H.S. (1999). Settlement and postsettlement interactions between Semibalanus balanoides (L.) (Crustacea: Cirripedia) and three species of fucoid canopy algae. Jor. Exp. Mar. Biol. Ecol. 236 (1999) 49-67. 1.

Jennings, S.; Boullé, D. and Polunin, N. V. C. (1996). Habitat correlates of the distribution and biomass of Seychelles reef fishes. Envi. Biol. Fish, 46: 15-25.

Jessen, C.; Roder, C.; Lizcano, J. V.; Voolstra, C.R. and Wild, C. (2012). Top-down and bottom-up effects on Red Sea coral reef algae. Proceedings of the $12^{\text {th }}$ International Coral Reef Symposium, Cairns, Australia, 9-13 July 2012 11A Ecology and macroecology: general session.

Kaufman, L. and Tschirky, J. (2010). Living with the sea. Science and Knowledge Division, Conservation International, Arlington, VA, USA.

Kaufman L, Sandin S, Sala E, Obura D, Rohwer F. and Tschirky, T. (2011). Coral Health Index (CHI): measuring coral community health. Science and Knowledge Division, Conservation International, Arlington, VA, USA.

Kotb, M.A.; Abdulaziz, M.; Al-Agwan, Z.; Alshaikh, K.; Al-Yami, H.; Banajah, A.; Devantier, L.; Eisinger, M.; Eltayeb, M.; Hassan, M.; Heiss, G.; Howe, S.; Kemp, J.; Klaus, R.; Krupp, F.; Mohamed, N.; Rouphael, T.; Turner, J. and Zajonz, U. (2004). Status of Coral Reefs in the Red Sea and Gulf of Aden in 2004. In: Wilkinson, C. (ed.) Status of Coral Reefs of the World, 2004; pp. 137154. Australian Institute of Marine Science, Townsville, Queensland, Australia, $1,301 \mathrm{pp}$.

Kotb, M. M. A.; Hanafy, M. H.; Rirache, H.; Matsumara, S.; Al-Sofyani, A. A.; Ahmed, A. G.; Bawazir, G. and Al-Horani, F. (2008). Status of coral reefs in the Red Sea and Gulf of Aden Region. In: Status of Coral Reefs of the World: 2008, Wilkinson, C.E. (ed.), Townsville (Australia): Global Coral Reef Monitoring Network and Reef and Rainforest Research Centre. pp. 67-78.

Lawton, R.J., and Pratchett, M.S. (2012). Influence of dietary specialization and resource availability on geographical variation in abundance of butterflyfishes. Ecol Evol In press.

Lecchini D, Adjeroud M, Pratchett M, Cadoret L, Galzin R (2003). Spatial structure in coral reef fish communities in the Ryukyu Islands, southern Japan. Ocean Acta, 26: 537-547.

McGehee, A. (1994). Correspondence between assemblages of coral reef fishes and gradients of water motion depth, and substrate size off Puerto Rico. Mar. Ecol. Prog. Ser, 105: 243-255.

Mellin, C.; Bradshaw, C. J. A; Meekan, M.G. and Caley. M.J. (2010). Environmental and spatial predictors of species richness and abundance in coral reef fishes, Glob. Ecol. Biogeogr, 19: 212-222. 
Mohammed, T.A., (2006). Evaluation, distribution and the coral diversity in some coastal lagoons, Red Sea, Egypt. Egyptian Journal of Aquatic Research 32, 180-195, Special issue.

Mohammed, T.A. (2012). Rapid Assessment of Coral Reefs along the Egyptian Red Sea Coast IJEP Vol. 2 No. 42012 PP. 25-33.

Mohammed, T.A., and Mohamed, M.A. (2005). Some ecological factors affecting coral reef assemblages off Ennadi, Red Sea, Egypt. Egyptian Journal of Aquatic Research 31 (1), 133-145.

Morton, J.K.; Platell, M.E.; and Gladstone, W. (2008). Differences in feeding ecology among three co-occuring species of wrasse (Teleostei: Labridae) on rocky reefs of temperate Australia. Mar Biol, 154:577-592.

Mumby, P.J., Steneck, R.S. (2011). The resilience of coral reefs and its implications for reef management. In: Dubinsky Z, Stambler N (eds) Coral Reefs: An ecosystem in transition. Springer, Amsterdam, pp 509-519.

Mumby, P.J.; Dahlgren, C.P.; Harborne, A.R.; Kappel, C.V.,;Micheli, F.; Brumbaugh, D.R.; Holmes, K.E.; Mendes, J.M.; Broad, K.; Sanchirico, J.N.; Buch, K., Box, S.; Stoffle, R.W. and Gill, A.B. (2006). Fishing, trophic cascades, and the process of grazing on coral reefs. Science, 311: 98-101.

Mumby, P.J.; Harborne, A.R.; Williams, J.; Kappel, C.V.; Brumbaugh, D.R.; Micheli, F.; Holmes, K.E.; Dahlgren, C.P.; Paris, C.B. and Blackwell, P.G. (2007). Trophic cascade facilitates coral recruitment in a marine reserve. Proceedings of the National Academy of Sciences DOI 10.1073/pnas.0702602104.

Mumby, P.t.; Flower, J.; Chollett, I.; Stephen J.B.; et al., (2014). Towards Reef Resilience and Sustainable Livelihoods: A handbook for Caribbean coral reef managers. University of Exeter, Exeter. 172 pages.

Munday, P.L.; Jones; G.P. and Caley, M.J. (1997). Habitat specialization and the distribution and abundance of coral-dwelling gobies. Mar. Ecol. Prog. Ser, 152: 227-239.

Nagelkerken, I.; van der Velde, G.; Gorissen; M. W.; Meijer, G. J.; van't Hof, T. and den Hartog, C. (2000). Importance of mangroves, seagrass beds and the shallow coral reef as a nursery for important coral reef fishes, using a visual census technique. Estuarine, Coast. Shel. Sci., 51: 31-44.

Nyström, M., and Folke, C. (2001). Spatial resilience of coral reefs. Ecosystems 4: 406-417.

Obura, D.O.; and Grimsdith, G. (2009). Resilience Assessment of coral reefs Assessment protocol for coral reefs, focusing on coral bleaching and thermal stress. IUCN working group on Climate Change and Coral Reefs. IUCN, Gland, Switzerland. 70 pages.

Obura, D. and Mangubhai, S. (2011). Coral mortality associated with thermal fluctuations in the Phoenix Islands, 2002-2005. Coral Reefs.

Öhman, M.C.; Rajasuriya, A. and Svensson, S. (1998). The use of butterflyfishes (Chaetdodontidae) as bio-indicators of habitat structure and human disturbance. Ambio, 27: 708-716.

PERSGA, (2010). The status of coral reefs in the Red Sea and Gulf of Aden: 2009. The regional organization for the conservation of the environment of the Red Sea and Gulf of Aden, Technical Series No. 16, 125p.

Porter, J. W.; and Tougas, J. I. (2001). Reef ecosystems: threats to their biodiversity. In: Encyclopedia of Biodiversity, Levin, S.A. (ed.), Vol. 5, San Diego: Academic Press, pp. 73-95. 
Pratchett, M.S.; Baird, A.H. and Marquis, C.P. (2000). Comparative palatability among eggs of mass-spawning corals. International Coral Reef Symposium, Bali, Indonesia 23-27 October 2000.

Pratchett, M.S; Hoey, A.S; Wilson, S.K; Messmer, V. Graham, N.A.J. (2011). Changes in the biodiversity and functioning of reef fish assemblages following coral bleaching and coral loss. Diversity, $3: 424-452$.

Pratchett, M. Hoey, A.; Coker, D. and Gardiner, N. (2012). Interdependence between reef fishes and scleractinian corals. Proceedings of the 12th International Coral Reef Symposium, Cairns, Australia, 9-13 July 2012 13C Ecological effects of habitat degradation.

Riegl, B.; Brunkner, A.; Rowlands, G; Purkis, S. and Renaud, P. (2012). Red Sea Coral Reef Trajectories over 2 Decades Suggest Increasing Community Homogenization and Decline in Coral Size. PLOS DOI: 10. 1371.

Richmond, R.H. (1987). Energetics, competency, and long-distance dispersal of planula larvae of the coral Pocillopora damicornis. Mar Biol, 93: 527-533.

Roberts, C.M.; Sheppard, A.R.D. and Ormond, R.F.G. (1992). Large-scale variation in assemblage structure of Red Sea butterflyfishes and angelfishes. Journal of Biogeography, 19: 239-250.

Russ, G.R. (1984a). Distribution and abundance of herbivorous grazing fishes in the central Great Barrier Reef. I. Levels of variability across the entire continental shelf. Marine Ecology Progress Series 20: 23-34.

Sale, P.F., Cowen, R.K.; Danilowicz, B.S.; Jones, G.P.,; Kritzer, J.P.; Lindeman, K.C.; Planes, S. Polunin, N.V.C.; Russ, G.R.; Sadovy, Y.J. and Steneck R.S. (2005). Critical science gaps impede use of no-take fishery reserves. Trend Ecol Evol 20:74-80.

Sheppard, C.R.C. (1982). Coral populations on reef slopes and their major controls. Marine Ecology Progress Series, 7: 83-115.

Sheppard, C.; Price, A. and Roberts, C. (eds.) (1992). Marine ecology of the Arabian Region. Academic Press New York. 359 pp.

Smith, J., Hunter, C. and Smith, C. (2010). The effects of top-down versus bottom-up control on benthic coral reef community structure. Oecologia, 163: 497-507.

Spalding, M.D.; Ravilious, C. and Green, E.P. (2001). World Atlas of Coral Reefs, Prepared at the UNEP World Conservation Monitoring Centre, University of California Press, Berkeley, USA.

Stake, J.L. and Sammarco, P.W. (2003). Effects of pressure on swimming behavior in planula larvae of the coral Porites astreoides (Cnidaria, Scleractinia). J Exp Mar Biol Ecol, 288: 181-201. doi: 10.1016/s0022-0981(03)00018-2

Tilot, V., Leujak, W., Ormond, R.F., Ashworth, J.A. and Mabrouk, A., (2008). Monitoring of South Sinai Coral Reefs: Influence of Natural and Anthropogenic Factors. Aquatic Conservation: Marine and Fresh Water Ecosystem. John Wiley Sons, Ltd.

Toda, T., Okashita, T., Maekawa, T., Alfian, B.A., Rajuddin, M.K., Nakajima, R., Chen, W., Takahashi, K.T., Othman, B.H. and Terazaki, M., (2007). Community structures of coral reefs around Peninsular Malaysia. Journal of Oceanography, 63: 113-123.

Tolimieri, N. (1998). The relationship among microhabitat characteristics, recruitment and adult abundance in the stoplight parrotfish, Sparisoma viridae, at three spatial scales. Bull. Mar. Sci., 62: 253-268.

Young, C.M. and Chia, F.S. (1987). Abundance and distribution of pelagic larvae as influenced by predation behavior and hydrological factors. Pages 385-463 In: 
Giese C, Pearse JS, Pearse VB (eds (Reproduction of marine invertebrates. Vol 9 .Blackwell Scientific Publications, California.

Wilkinson, C. (2004). Status of coral reefs of the world. AIMS: Townsville (Australia), $557 \mathrm{pp}$.

Wilkinson, C. (2008) Status of Coral Reefs of the World: 2008 Global Coral Reef Monitoring Network and Reef and Rainforest Research Centre, Townsville, Australia, $296 \mathrm{p}$.

Williams D. McB. (1982). Patterns in the distribution of fish communities across the central Great Barrier Reef. Coral Reefs, 1: 35-43.

Williams, D. McB. (1991). Chapter 16 Patterns and processes in the distribution of coral reef fishes. In: Sale, P.F. (ed) The Ecology of Fishes on Coral Reefs. Academic Press, Sydney. 